\title{
NEWS
}

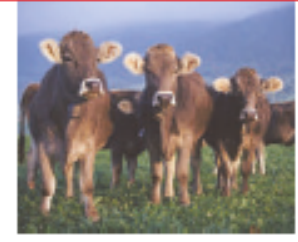

\section{Europe condemns Libyan trial verdict}

Bulgaria's accession to the European Union (EU) on 1 January will allow it to apply evergreater international pressure in the political row over the fate of five Bulgarian nurses and a Palestinian doctor condemned to death in Libya last month.

The six medical workers were sentenced to death on 19 December by the Benghazi Criminal Court for deliberately infecting more than 400 children with HIV at the Al-Fateh Hospital in Benghazi in 1998. Scientists around the world have argued that medical evidence shows unequivocally that the people were not infected deliberately. They point out that the outbreak was a typical example of what can go wrong when hospital equipment and supplies become contaminated - as happened in a hospital in Kazakhstan, where more than 80 children were infected with HIV last summer.

The team defending the medical workers says that it will appeal the verdict to the Supreme Court in Libya. By law, this must be done within 60 days of the verdict. The Supreme Council for Judicial Authority could also annul the death sentences. The council, which makes judicial appointments, is an interface between Libyas supposedly separated executive and judiciary authorities.

Although the strongest criticism of the verdict came from Bulgaria itself, both the EU and Germany, which holds the EU's presidency for the first half of 2007 , forcefully condemned the sentences. Bulgaria's new status as an EU member state seems to ensure that this pressure will not slacken.

"We simply cannot accept this verdict," says Benita Ferrero-Waldner, the European Commission's foreign minister.

In a letter to the Libyan foreign ministry she pointed to the "recent publication of a strong body of scientific evidence concerning the origin and timing of the Benghazi infection...I very much regret that this new element was not deemed worth considering in the legal proceedings thus far and hope it will beduly taken into consideration by the Supreme Court."

German Chancellor Angela Merkel condemned the verdict as a "terrible ruling"; FrankWalter Steinmeier, Germany’s foreign minister, said that the EU would "continue to exert pressure under the German presidency so that Libya doesn't only take part in a solution but ultimately brings about a solution. This toughened attitude contrasts sharply with that shown by the United States. President George Bush and Secretary of State Condoleezza Rice expressed only "disappointment", and have avoided any discussion of a fair trial or the need for scientific evidence to be taken into account.

The EU's direct language raises the stakes in the power play that surrounds the case. Until now, the international community's approach in the running of the Libyan justice system or to challenge its equity or fairness." Libyan state-controlled media have also orchestrated a campaign trying to equate the questioning of the guilt of the health workers with indifference to the plight of the children. Some allege that critics are part of a Western conspiracy. ${ }^{\text {"I Is }}$ the blood of our children mere sewer water?" asked the El Jamahiriya newspaper.

When the six medical workers were arrested in 1999, the country's leader Colonel Gaddafi stoked up sentiments such as these by alleging that the infection was a plot by the US Central Intelligence Agency (CIA) and Israel's intelligence agency the Mossad to destabilize the country. Since then, Libya's geopolitical position has changed. After it abandoned the pursuit of weapons of mass destruction in 2003, providing the West with intelligence on nuclear proliferation, the oncerogue state came to be seen as a partner in the 'war on terror'. When diplomatic ties with the United States and the EU were subsequently re-established and trade sanctions lifted, busi- has mostly been one of 'silent diplomacy' - refraining from public criticism of Libya's handling of the case and relying on behindthe-scenes discussions. These interventions have centred on providing humanitarian aid, which might be seen as compensation (and thus a mitigating factor in Islamic law), while trying not to undercut the medical workers' defence with any implication of guilt and atonement. All the affected Libyan children are being treated in European hospitals.

The death sentences mark the failure of this approach, says Emmanual Altit, the French human-rights lawyer who heads the international defence team. Altit has long criticized the politicization of the case, arguing that it acts against the interests of the six medical workers by making them a bargaining chip in Libya's relations with the West.

Now that the political outcry has become noisier, it has been met with anger from Libya. Said Hafyana, the deputy secretary for external relations and international cooperation in Libya's General People's Committee, told Bulgaria's ambassador to Libya that: ${ }^{\alpha}$ No party, no country or authority has the right to intervene ness from America and other nations flocked to the country, which has substantial untapped oil reserves.

The United States is expected to appoint an ambassador to Libya in the coming months, and a visit by Rice seems likely. Sean McCormack, the official spokesman for the US Department of State, says that the verdict itself would not block such moves, and is only one of many considerations. The United States does not intend to take sides in the case, he adds.

Libya's leadership now has greater incentive than ever to avoid diplomatic ructions; but there is substantial resistance to being seen as capitulating to pressure from the West. Gaddafi dug in his heels on 29 December by rejecting calls to release the medical team, and reasserting that intelligence agencies were behind the crime.

According to diplomatic sources, the most optimistic outcome for the moment is that the six medical workers will remain condemned, but that a political solution will be found to have them freed. But the situation is increasingly volatile - and for the moment they remain in grave danger.

Declan Butler

See Editorial, page 2. 